\title{
Soft Tissue Recurrence with a Mucocele of an Intraosseous Ameloblastoma
}

\author{
Hiromitsu Yamamoto', Ken-Ichiro Murakami², Mariko Kawai, ${ }^{1,3}$, Hitoshi Nagatsuka4, \\ Kazuhisa Bessho ${ }^{1}$
}

\author{
${ }^{1}$ Department of Oral and Maxillofacial Surgery, Graduate School of Medicine, Kyoto University, Kyoto, Japan \\ ${ }^{2}$ Department of Oral and Maxillofacial Surgery, Ako City Hospital, Ako, Japan \\ ${ }^{3}$ Department of Pharmacology, Osaka Dental University, Osaka, Japan \\ ${ }^{4}$ Department of Oral Pathology and Medicine, Graduate School of Medicine and Dentistry, Okayama University, Okayama, Japan \\ Email: hyama motokuhp@mac.com
}

How to cite this paper: Yamamoto, H., Murakami, K.-I., Kawai, M., Nagatsuka, H. and Bessho, K. (2017) Soft Tissue Recurrence with a Mucocele of an Intraosseous Ameloblastoma. Open Journal of Stomatology, 7, 336-344.

https://doi.org/10.4236/ojst.2017.78028

Received: July 6, 2017

Accepted: July 29, 2017

Published: August 1, 2017

Copyright $\odot 2017$ by authors and Scientific Research Publishing Inc. This work is licensed under the Creative Commons Attribution International License (CC BY 4.0).

http://creativecommons.org/licenses/by/4.0/

\begin{abstract}
Ameloblastoma is an odontogenic tumor of high frequency and usually occurs as an intraosseous growth. Ameloblastomas frequently recur, sometimes undergoing malignant transformation. These tumors are usually characterized as being multilocular, of the follicular type histopathologically, and invading strongly at the border region of the tumor. More than 10\% p53-positive tumor cells give a prognostic indication for a tendency to recur. A recurrent ameloblastoma usually occurs in the intraosseous region near the site of the original lesion. In very rare cases, a recurrent tumor proliferates distantly from the original site in the soft tissue only. We report a rare case of recurrent ameloblastoma in the buccal mucosa with a mucocele that originated from the small salivary glands after the extirpation of an intraosseous (mandibular) ameloblastoma. We also performed a p53 immunohistochemical study of this recurrent tumor.
\end{abstract}

\section{Keywords}

Ameloblastoma, Soft Tissue Recurrence, Follicular Type, Mucocele, p53

\section{Introduction}

Ameloblastoma is a benign odontogenic tumor that almost always occurs in the intraosseous region and has various histological forms. There are many reports of recurrent cases. Based on histopathology, the follicular type is more likely to recur than the plexiform type in the solid/multicystic type [1] [2]. Other characteristics of this tumor are a multilocular or cellular appearance in X-ray images, 
invading cells at the border of the tumor, and the presence of cylinder cells in the external region of the tumor nests [3] [4].

Recurrent ameloblastomas usually occur in the intraosseous region near the site of the original lesion. There are a few reports of recurrent tumor growth in the soft tissue [4]-[14]. Most of these recurrent cases required a large-scale operation, like hemi mandibulectomy or mandibular resection [4] [5] [6] [9] [10] [11]. We examined clinically and histopathologically a rare case in which ameloblastoma recurred in the buccal mucosa after the extirpation of an intraosseous (mandibular) ameloblastoma. The adjacent mandible and its periosteum were normal, and no continuity was observed between the tumor and mandible.

The p53 gene is one of the tumor suppressor genes, and its expression or mutation has been examined in tumors such as oral squamous cell carcinoma or leukoplakia. It has also been studied in odontogenic tumors including ameloblastoma [15]-[23]. Appel et al. reported that the immunohistochemical verification of more than $10 \%$ p53-positive ameloblastoma cells gives a prognostic indication for a tendency to recur [15]. We also examined p53 expression in this recurrent tumor immunohistochemically.

\section{Case Report}

A 42-year-old man presented to the Department of Oral and Maxillofacial Surgery, Kyoto University Hospital, for evaluation of a painless swelling in his left buccal mucosa. He had undergone extirpation of a mandibular/intraosseous ameloblastoma around the left lower canine tooth at another hospital just three years earlier. However, he later became aware of a painless swelling in the left buccal mucosa that gradually increased. Examination showed a $30-\mathrm{mm}$, painless, movable, hard, and elastic mass in the left buccal mucosa, in the lateral region of the mental foramen. A mass of the same size could be felt by extraoral palpation, although the man's features were normal (Figure 1). X-ray images of the original lesion showed a well-defined monolocular radiolucency with a uniform outline within some calcified tissues and an impacted crown of the left lower canine tooth. However, the radiolucency we observed was lower than that seen immediately following the previous operation (Figure 2). Computed tomography showed a well-defined, nonenhancing, $30 \times 27 \times 13$-mm tumor mass with some calcified tissues in the external left mandible. The mandibular bone was symmetric and showed no abnormalities (Figure 3). The clinical diagnosis was a benign tumor in the left buccal mucosa.

Tumor resection was performed under general anesthesia. After an incision was made just over the mass, a mucocele wall could be observed. However, the gray-colored tumor parenchyma was present just under the mucocele. Moreover, the rapid histopathological findings suggested the tumor was malignant. Tumor resection was then performed with a $10-\mathrm{mm}$ safety margin around the induration. The adjacent mandible and its periosteum were normal, and no continuity was observed between the tumor and mandible. The resected tissue is shown in Figure 4. 

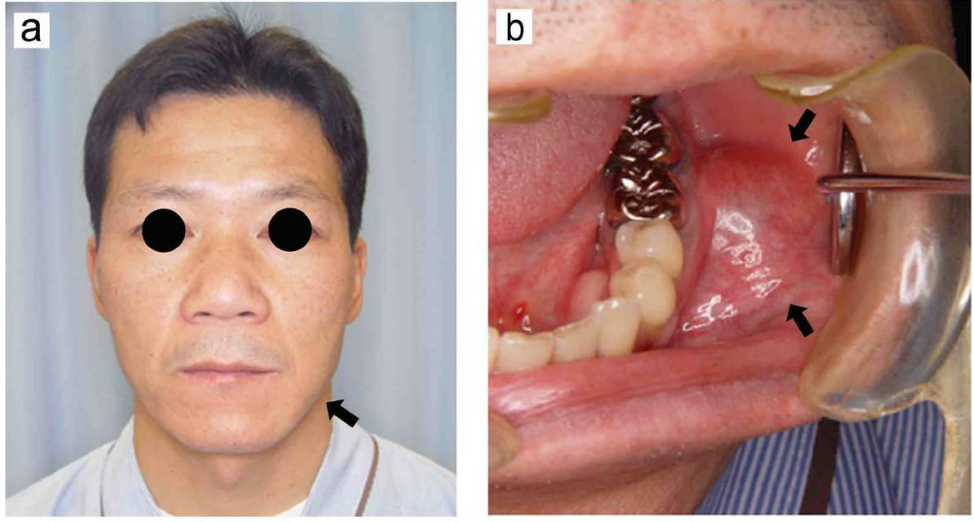

Figure 1. (a). Extraoral examination revealed a mass that could be detected by palpation, although the patient's features were normal; (b). Intraoral examination showed a $30-\mathrm{mm}$, painless, movable, hard, and elastic mass in the left buccal mucosa in the lateral region of the mental foramen.
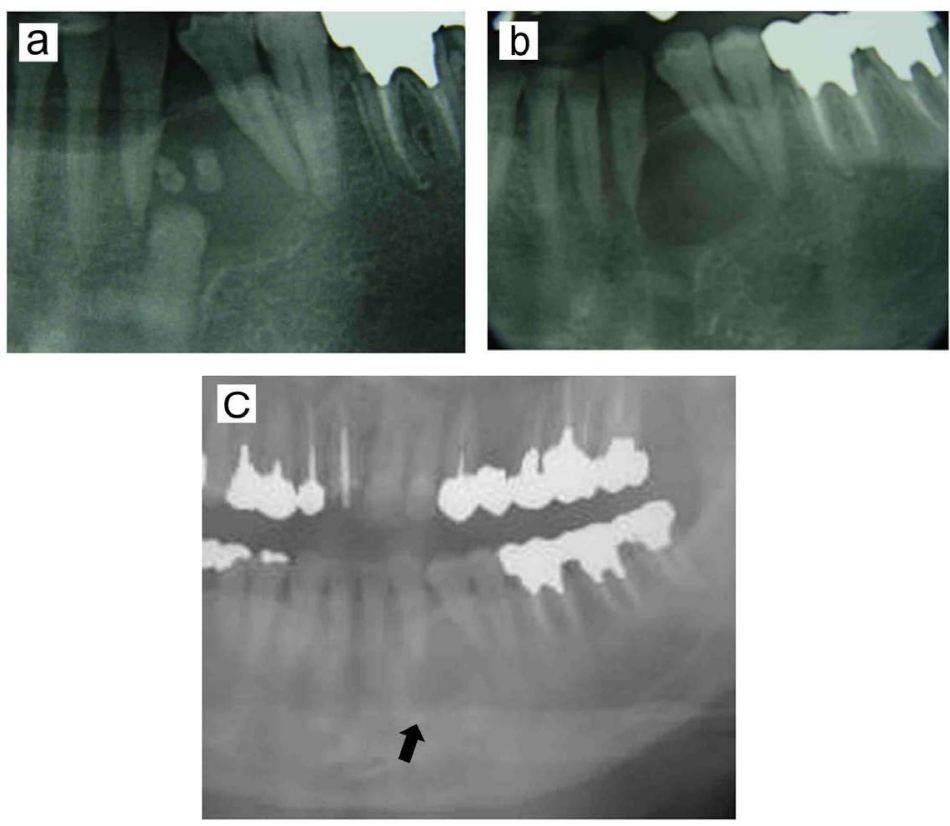

Figure 2. (a). X-ray results of the original lesion. A well-defined monolocular radiolucency with a uniform outline within some calcified tissues and an impacted crown of the left lower canine tooth were observed; (b). X-ray results immediately after the operation; (c). X-ray results at the time of our examination. The radiolucency is lower than in (b).

Histopathological analysis showed ameloblastic cells in a palisading pattern at the marginal nests, and proliferating adamantinoid nests in the tumor. In addition, strong tumor invasion to the connective tissue was apparent, with partial necrosis in the nests and squamoid metaplasia. Although the tumor showed only slight nuclear dysplasia, disorder of the peripheral palisade in the nests, and many small nests, it did not show severe dysplasia and mitosis. The histopathological diagnosis was follicular type ameloblastoma, which recurred in the soft 


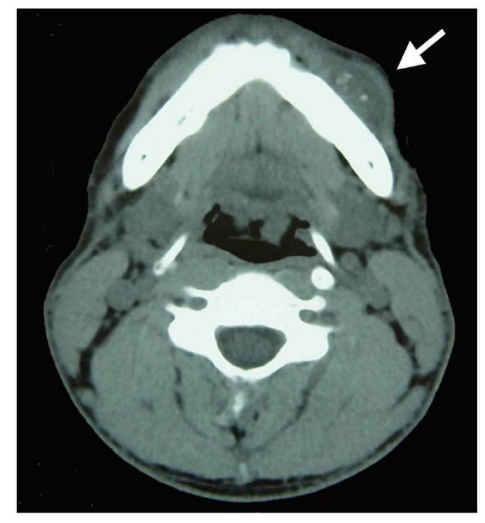

Figure 3. Computed tomography showed a well defined, nonenhancing, $30 \times 27 \times 13$-mm tumor mass with some calcified tissues in the external left mandible. Mandibular bone was symmetric and showed no apparent abnormality.

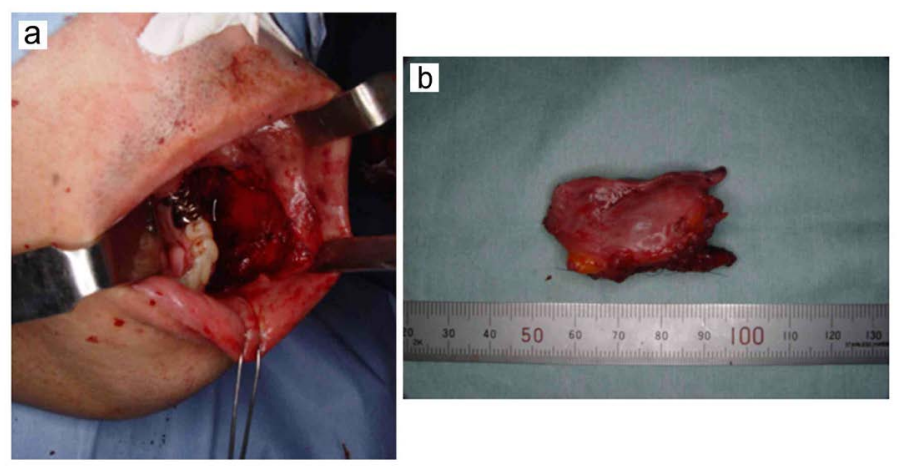

Figure 4. (a). Tumor resection was performed with a $10-\mathrm{mm}$ safety margin around the region of induration. The adjacent mandible and its periosteum were normal, and no continuity was observed between the tumor and mandible; (b). The resected tissue is shown.

tissue only (Figure 5). On the other hand, the original tumor cells showed substantiality and sheet-like proliferation. External tumor nests were formed by cylinder cells, and the nests in the central region by spindle or asteroid cells. No dysplasia or mitosis was observed in the tumor cells. This original tumor was diagnosed as being of the plexiform type partly mixed with the follicular type (Figure 6).

The immunohistochemical examination for p53 demonstrated that approximately $10 \%$ of the cells observed on the sections were p53-positive (Figure 7). This examination was explained to the patient in detail and he gave his consent in writing. No symptoms of recurrence have been found more than three years. However, strict follow-up will be necessary.

\section{Discussion}

We reported here a rare case of recurrent ameloblastoma in the buccal mucosa with a mucocele, occurring after extirpation of an intraosseous ameloblastoma. 

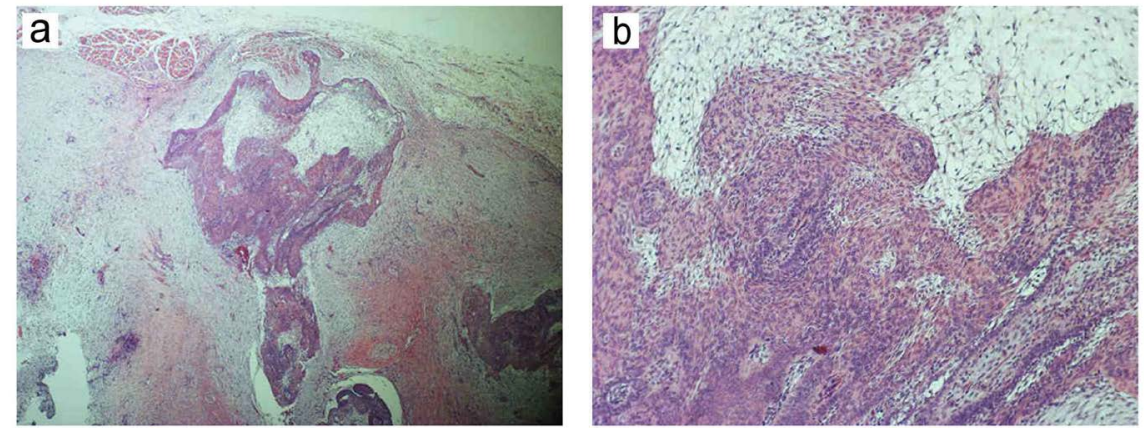

Figure 5. Histopathological results. The pathological diagnosis was follicular type ameloblastoma. Ameloblastic cells formed a palisading pattern at the marginal nests, and the tumor had proliferating adamantinoid nests. Tumor invasion to the connective tissue was strong with partial necrosis in the nests, and squamoid metaplasia. (Haematoxylin and eosin; original magnification, (a): $\times 25$, (b): $\times 100)$.

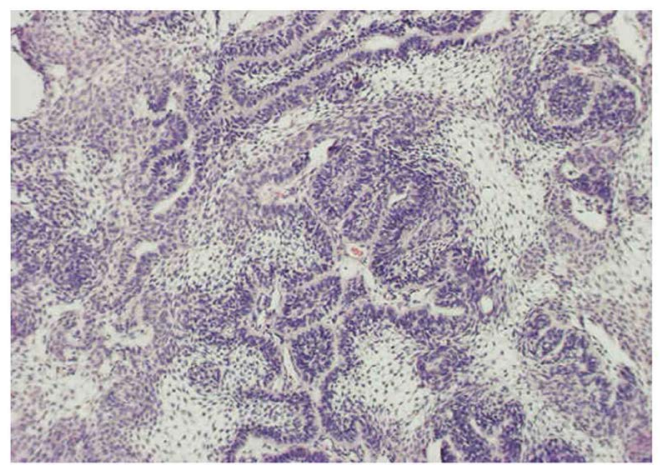

Figure 6. Histopathological findings for the original lesion. The pathological diagnosis was the plexiform type partly mixed with the follicular type. Tumor cells showed substantiality and sheet-like proliferation. The external tumor nests were formed by cylinder cells, and those in the central region by spindle or asteroid cells. (Haematoxylin and eosin; original magnification, $\times 100)$.

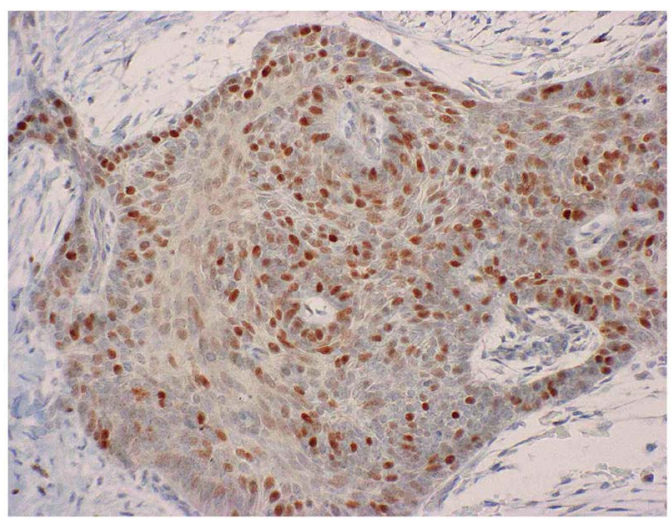

Figure 7. Immunohistochemical examination demonstrated p53-positive cells in the tumor on the sections. Approximately $10 \%$ of the cells observed on the sections were p53positive. (Original magnification, $\times 200$ ).

In this case, because the X-ray images of the original lesion showed a well-defined monolocular radiolucency with a uniform outline and it was diagnosed as 
the plexiform type partly mixed with the follicular type, the recurrence of this tumor therefore did not follow the general tendency indicated in previous reports. The histopathological analysis of the tumor nest and the area around the tumor, however, indicated that the tumor could easily recur, because the external cells of the nests included cylinder cells, there were abundant, partially formed collagen fibers, and the nests invaded non-continuously into the connective tissue.

Ameloblastoma is known as a benign tumor, but it can also be malignant, which is very difficult to diagnose, since it has multiple pathological patterns and only occasionally shows strong nuclear dysplasia or mitosis. In our case, the rapid histopathological examination during the operation showed the nests formed by epithelium had a strongly invasive character, suggesting that the tumor had been malignant for a while. Moreover, in cases where tumor recurs in a region disconnected from the original site of an odontogenic tumor, it sometimes has different pathological characteristics from the original tumor [10]. Similarly, in our case, the diagnosis of the original lesion was different from that of the recurrent tumor. The histopathological character of the recurrent lesion typically shows densely aligned cylinder cells at the external region of the tumor nests, and some basal-like cells or squamoid metaplasia, in addition to characteristics of the follicular type [24]. The recurrent lesion in this case was of the follicular type, and it showed partial squamoid metaplasia, although no basal-like cells were present. The density of cells forming the nests was very high, and both the inducement of mesenchymal tissues and invasion into the connective tissues was significantly higher than in the original lesion.

The candidates for the differential diagnosis included peripheral ameloblastoma, calcifying odontogenic cyst, and any tumors of the salivary gland. No typical findings for tumors of the salivary gland were observed. After due consideration of the tumor's progress, we determined that this case was a recurrent ameloblastoma in the buccal mucosa. Peripheral ameloblastoma appears to arise directly from the oral mucosa outside the bone [25] [26] [27] [28] [29]. Since this patient had a history of extirpation from the mandible, this disease was not targeted in the differential diagnosis.

There are many recurrent cases of ameloblastoma, most of which occur at an intraosseous site near the original lesion. However, a few cases of recurrence involving autogenous bone grafts have also been reported [10] [30]. A few cases of soft tissue recurrence have been reported [4]-[11], and most of them required large-scale operations, such as hemi mandibulectomy or mandibular resection [4] [5] [6] [9] [10] [11]. Besides our case, there are few reports of cases in which the original lesion was comparatively small and was treated only by extirpation, with tumor recurrence in the soft tissue. Our observation during the operation of the external region of the mandible around the left mental foramen, the site of the original lesion, revealed no abnormalities on or in the mandible, and its periosteum was normal. These findings indicated that, in this case, the recurrent 
tumor did not extend from the intraosseous lesion to the external soft tissue, but arose spontaneously in the soft tissue only. Soft tissue recurrence is attributable to inadequate surgical treatment or to the dissemination of tumor cells to the surrounding tissue [5] [6] [7]. In this case, it is likely that dissemination upon extirpation of the original tumor occurred, and then because there were many small salivary glands, the recurrent tumor formed a mucocele on its increasing surface.

In ameloblastomas, as in many other malignant tumors, the expression or mutation of p53 has been examined [15]-[23]. Appel et al. reported that the immunohistochemical verification of more than $10 \%$ p53-positive tumor cells gives prognostic indication for a tendency of the tumor to recur [15]. Our immunohistochemical examination of the p53 expression in this recurrent tumor showed approximately $10 \%$ p53-positive cells on the sections, which is consistent with the findings of Appel et al.

Because ameloblastomas can arise spontaneously in the soft tissue, both an appropriate surgical plan and treatment designed to prevent tumor dissemination and long-term follow-up are important.

\section{Conclusion}

We reported a rare case of recurrent ameloblastoma in the buccal mucosa with a mucocele originating from the small salivary glands after the extirpation of an intraosseous (mandibular) ameloblastoma. In addition, we showed that approximately $10 \%$ of the cells in this recurrent tumor were p53-positive.

\section{Consent}

Written informed consent was obtained from the patient for publication of this case report ant any accompanying figures.

\section{References}

[1] Reichart, P.A., Philipsen, H.P. and Sonner, S. (1995) Ameloblastoma: Biological Profile of 3677 Cases. European Journal of Cancer Part B: Oral Oncology, 31B, 8699.

[2] Philipsen, H.P. and Reichart, P.A. (1998) Unicystic Ameloblastoma. A Review of 193 Cases from the Literature. Oral Oncology, 34, 317-325.

[3] Takeuchi, N. (1996) Studies of Proliferative Ability of Ameloblastoma. Journal of Nara Medical Association, 47, 111-123.

[4] Tohya, T., Kawahara, K., Hotta, F., Shirozu, T., Miyachi, H. and Mizushima, M. (2001) A Case of Recurrent Ameloblastoma in Soft Tissue 21 Years after Segmental Resection of a Tumor. Japanese Journal of Oral and Maxillofacial Surgery, 47, 350 353. https://doi.org/10.5794/jjoms.47.350

[5] Al-Bayaty, H.F., Murti, P.R., Thomson, E.R.E. and Niamat, J. (2002) Soft Tissue Recurrence of a Mandibular Ameloblastoma Causing Facial Deformity in the Temporal Region: Case Report. Journal of Oral and Maxillofacial Surgery, 60, 204-207. https://doi.org/10.1053/joms.2002.29826 
[6] Ferretti, C., Polakow, R. and Coleman, H. (2000) Recurrent Ameloblastoma: Report of 2 Cases. Journal of Oral and Maxillofacial Surgery, 58, 800-804. https://doi.org/10.1053/joms.2000.7271

[7] Olasoji, H.O., Nggada, H.A. and Tahir, A.A. (2004) Recurrence of Multicystic Ameloblastoma in Soft Tissue. Tropical Doctor, 34, 112-114. https://doi.org/10.1177/004947550403400223

[8] Sampson, D.E. and Pogrel, M.A. (1999) Management of Mandibular Ameloblastoma: The Clinical Basis for a Treatment Algorithm. Journal of Oral and Maxillofacial Surgery, 57, 1074-1079.

[9] Kaneda, T., Watanabe, F., Kato, Y., Tatematsu, N. and Oka, N. (1984) Recurrent Ameloblastoma in Soft Tissue 10 Years Later Iliac Bone Graft. Journal of the Japan Stomatological Society, 33, 445-451.

[10] Iida, M., Sato, T., Yoshitake, K., Furutani, M., Kawasaki, T. and Yamaguchi, Y. (1983) Recurrent Ameloblastoma 11 Years Later in the Mandibular Reconstruction Region Transplanted Using the Ilium. Japanese Journal of Oral and Maxillofacial Surgery, 29, 865-872. https://doi.org/10.5794/jjoms.29.865

[11] Yamamoto, E., Kyogoku, J., Fukuda, O., Abe, K. and Kohama, G. (1986) Recurrent Ameloblastoma Following Hemimandibulectomy: Report of a Case. Japanese Journal of Oral and Maxillofacial Surgery, 32, 2120-2126. https://doi.org/10.5794/jjoms.32.2120

[12] Adebayo, E.T., Fomete, B. and Adekeye, E.O. (2011) Delayed Soft Tissue Recurrence after Treatment of Ameloblastoma in a Black African: Case Report and Review of the Literature. Journal of Cranio-Maxillo-Facial Surgery, 39, 615-618.

[13] Xavier, S.P., Faria, A.C., de Mello Filho, F.V., Silva, E.R. and de Santana Santos, T. (2013) Recurrence of Ameloblastoma in Soft Tissue. Journal of Craniofacial Surgery, 24, 1866-1867. https://doi.org/10.1097/SCS.0b013e31829a84a1

[14] Lin, Z., Sun, G., Wang, T., Hu, Q., Chen, F. and Wen, S. (2015) Soft Tissue Recurrent Ameloblastomas Also Show Some Malignant Features: A Clinicopathological Study of a 15-Year Database. Medicina Oral, Patologia Oral Y Cirugia Bucal, 20, 365-371. https://doi.org/10.4317/medoral.20276

[15] Appel, T., Gath, R., Wernert, N., Martini, M. and Berge, S. (2004) Molecular Biological and Immunohistochemical Analysis of tp53 in Human Ameloblastoma. Mund-Kiefer-Gesichtschirurgie, 8, 167-172. https://doi.org/10.1007/s10006-004-0539-7

[16] Kumamoto, H., Izutsu, T., Ohki, K., Takahashi, N. and Ooya, K. (2004) p53 Gene Status and Expression of p53, MDM2, and p14 Proteins in Ameloblastomas. Journal of Oral Pathology \& Medicine, 33, 292-299. https://doi.org/10.1111/j.0904-2512.2004.00044.x

[17] Shibata, T., Nakata, D., Chiba, I., Yamashita, T., Abiko, Y., Tada, M. and Moriuchi, T. (2002) Detection of TP53 Mutation in Ameloblas toma by the Use of a Yeast Functional Assay. Journal of Oral Pathology \& Medicine, 31, 534-538. https://doi.org/10.1034/j.1600-0714.2002.00006.x

[18] Nodit, L., Barnes, L., Childers, E., Finkelstein, S., Swalsky, P. and Hunt, J. (2004) Allelic Loss of Tumor Suppressor Genes in Ameloblastic Tumors. Modern Pathology, 17, 1062-1067. https://doi.org/10.1038/modpathol.3800147

[19] Kitkumthorn, N., Yanatatsaneejit, P., Rabalert, J., Dhammawipark, C. and Mutirangura, A. (2010) Association of P53 Codon 72 Poly Morphism and Ameloblastoma. Oral Diseases, 16, 631-635. https://doi.org/10.1111/j.1601-0825.2010.01664.x 
[20] Salehinejad, J., Zare-Mahmoodabadi, R., Saghafi, S., Jafarian, A.H., Ghazi, N., Rajaei, A.R. and Marouzi, P. (2011) Immunohistochemi Cal Detection of p53 and PCNA in Ameloblastoma and Adenomatoid Odontogenic tumor. Journal of Oral Science, 53, 213-217. https://doi.org/10.2334/josnusd.53.213

[21] Sharifi-Sistani, N., Zartab, H., Babakoohi, S., Saghravanian, N., Jamshidi, S., Esmaili, H., Mohtasham, N., Zamanzadeh, M. and Abbaszadeh-Bidokhty, H. (2011) Immunohistochemical Comparison of the Expression of p53 and MDM2 Proteins in Ameloblastomas and Keratocystic Odontogenic Tumors. Journal of Craniofacial Surgery, 22, 1652-1656. https://doi.org/10.1097/SCS.0b013e31823188e9

[22] Florescu, A., Simionescu, C., Ciurea, R. and Pitru, A. (2012) p53, Bcl-2 and Ki67 Immunoexpression in Follicular Solid Ameloblastomas. Romanian Journal of Morphology and Embryology, 53, 105-109.

[23] Singh, T., Chandu, A., Clement, J. and Angel, C. (2017) Immunohistochemistry of Five Molecular Markers for Typing and Management of Ameloblastomas: A Retrospective Analysis of 40 Cases. Journal of Maxillofacial and Oral Surgery, 16, 6570. https://doi.org/10.1007/s12663-016-0923-5

[24] Kubota, H., Honma, M., Yamada, T., Ookubo, J. and Matsuda, N. (1978) Recurrence and Histopathologic Changes of Ameloblastoma. Japanese Journal of Oral and Maxillofacial Surgery, 24, 103-107. https://doi.org/10.5794/jjoms.24.103

[25] Ramnarayan, R.G. and Antony, G.K. (1985) Peripheral Ameloblastoma. International Journal of Oral Surgery, 14, 300-301.

[26] El-Mofty, S.K., Gerard, N.O., Farish, S.E. and Rodu, B. (1991) Peripheral Ameloblastoma: A Clinical and Histologic Study of 11 Cases. Journal of Oral and Maxillofacial Surgery, 49, 970-975.

[27] Philipsen, H.P., Reichart, P.A., Nikai, H., Takata, T. and Kudo, Y. (2001) Peripheral Ameloblastoma: Biological Profile Based on 160 Cases from the Literature. Oral Oncology, 37, 17-27.

[28] Wettan, H.L., Patella, P.A. and Freedman, P.D. (2001) Peripheral Ameloblastoma: Review of the Literature and Report of Recurrence as Severe Dysplasia. Journal of Oral and Maxillofacial Surgery, 59, 811-815.

https://doi.org/10.1053/joms.2001.24302

[29] LeCorn, D.W., Bhattacharyya, I. and Vertucci, F.J. (2006) Peripheral Ameloblastoma: A Case Report and Review of the Literature. Journal of Endodontics, 32, 152 154.

[30] Martines, W.D., Favaro, D.M. and Paranavai, C. (2004) Recurrence of an Ameloblastoma in an Autogenous Iliac Bone Graft. Oral Surgery, Oral Medicine, Oral Pathology, Oral Radiology, 98, 657-659. 
Submit or recommend next manuscript to SCIRP and we will provide best service for you:

Accepting pre-submission inquiries through Email, Facebook, LinkedIn, Twitter, etc. A wide selection of journals (inclusive of 9 subjects, more than 200 journals)

Providing 24-hour high-quality service

User-friendly online submission system

Fair and swift peer-review system

Efficient typesetting and proofreading procedure

Display of the result of downloads and visits, as well as the number of cited articles Maximum dissemination of your research work

Submit your manuscript at: http://papersubmission.scirp.org/

Or contact ojst@scirp.org 